\title{
Ocular Damage in the Battered-baby Syndrome
}

\author{
ALAN S. MUSHIN
}

British Medical fournal, 1971, 3, 402-404

\section{Summary}

Twelve out of 19 battered babies seen with ocular damage have permanent impairment of vision affecting one or both eyes. Ocular disease, especially retinal haemorrhage, is common in the battered-baby syndrome, and infants with this condition should always have a complete ophthalmic examination.

\section{Introduction}

For many centuries child abuse has been known to occur, but only recently has severe physical trauma to young children been noted as an entity by the medical profession. Caffey (1946) first reported the unusual combination of recurrent subdural haematoma with fractures of the long bones, but he thought the picture could be accounted for on the basis of a metabolic abnormality. Silverman (1953) was the first to point out that both the subdural haematoma and the bony changes were the result of severe recurrent trauma. Adelson (1961) drew attention to the problem, and Kempe et al. (1962) coined the term "battered child syndrome" to describe these children. The emotive term "battered baby" is now in common use.

Ocular damage in battered children is not common, apart from transient retinal haemorrhages in cases of subdural haematomata, but a few more severe injuries have been described. Kiffney (1964) described a case of traumatic retinal detachment in a battered child and remarked that batteredchild syndrome should always be considered in the diagnosis of retinal detachment in infants. Gilkes and Mann (1967) drew attention to retinal haemorrhages following cerebral trauma in these cases, and Maroteaux et al. (1967) and Maroteaux and Lamy (1967) reported similar cases in France.

In this paper 12 cases of battered-child syndrome in which vision has been permanently impaired are presented.

\section{Case 1}

This baby was treated for a fracture of the right leg at the age of $2 \frac{1}{2}$ months and a fracture of the skull at 4 months. The parents were unable to explain how the fractures had occurred. At $4 \frac{1}{2}$ months she was again admitted to hospital with abdominal pain and blood in the stools. A diagnosis of intussusception was made, but the trouble subsided without operation. At the age of 7 months the child was admitted to Hammersmith Hospital because the mother noticed a swelling on the baby's head and a further skull fracture was suspected.

On admission the child looked pale and ill and there was bruising over the right frontal region. She was of small stature, being below the third percentile for both height and weight. It was noticed that the left eye seemed smaller than the right and that a retrolental opacity was present.

Investigations. - Haemoglobin $11 \cdot 1 \mathrm{~g} / 100 \mathrm{ml}$ on 5 August 1969 and $9.8 \mathrm{~g}$ on 19 August. Serum total protein $6.7 \mathrm{~g} / 100 \mathrm{ml}$. Cal-

London Hospital, London E1 1BB

ALAN S. MUSHIN, F.R.c.s., D.o., Consultant Ophthalmic Surgeon cium $5.6 \mathrm{mN}$. Inorganic phosphorus $3.4 \mathrm{mN}$. Alkaline phosphatase 14 K.A. units. $X$-ray examination of arms, spine, abdomen, both lower legs showed no lesion. $X$-ray examination of skull showed bilateral fractures of occipital bone. Urine: no deposit, no growth. Blood: Wassermann reaction negative, fluorescent treponemal antibody test negative. Toxoplasma complement fixation test negative $1: 4$. Rubella haemagglutination inhibition test negative $1: 16$

Ocular Examination.-The eyes were straight and there was no squint. Ocular movements were full. The right eye appeared normal and the pupil reacted briskly to direct light but not consensually. The left pupil did not react to light and the eye appeared smaller than the right.

Examination under Anaesthesia.-Right eye: tension $16 \mathrm{~mm}$ $\mathrm{Hg}$ (Schiøtz); corneal diameter $11 \mathrm{~mm}$; anterior segment normal lens .and vitreous clear; small pigmented scar in the peripheral fundus at 9 o'clock. The electroretinogram was normal in wave form and amplitude. Left eye: tension $14 \mathrm{~mm} \mathrm{Hg}$ (Schiøtz); corneal diameter $9.5 \mathrm{~mm}$; lens subluxated up and in (Fig. 1); iris atrophy above. The retina was totally detached and very folded, with a good deal of pigment scattered on the surface of the fold (Fig. 2). (Examination with the microscope showed no evidence of intraocular inflammation.) Electroretinogram was not obtainable. There has been no change during the past year in either eye.

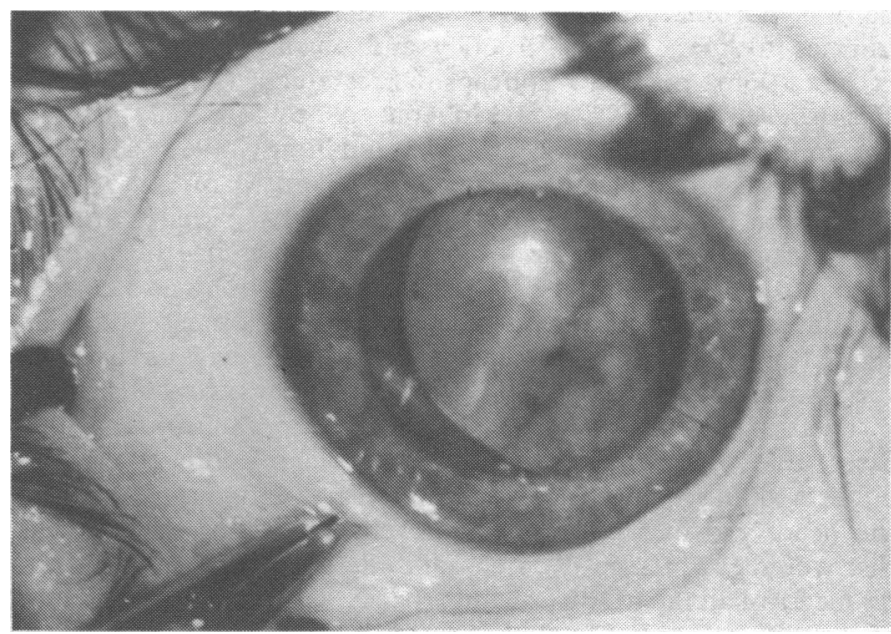

FIG. 1-Case 1. Left eye showing the subluxated lens and pigment of the surface of the detached retina.

\section{Case 2}

This child was cared for by a "baby-minder" during the day while both parents were at work. At the age of 8 months he was brought to hospital as an emergency case and found to have a bulging anterior fontanelle and bilateral retinal haemorrhages. No definite cause was established but it was suspected that he had been struck on the head with a hammer. He rapidly became drowsy and was transferred to a neurosurgical unit. $\mathrm{He}$ was found to have bilateral subdural haematomata, and both fontanelles were needled to evacuate the blood. This was repeated several times, and eventually biparietal burr holes were made. The haematomata still did not clear, and a subduroperitoneal shunt 
was fashioned. After a stormy course the child recovered. The haemorrhages in the right fundus cleared when the intracranial pressure was reduced, but in the left eye the subhyaloid haemorrhage broke through into the vitreous.

He was not brought for follow-up and was next seen six months later with a painful swollen left eye. Examination showed the left eye to be larger than the right (corneal diameters: right $11 \mathrm{~mm}$, left $13 \mathrm{~mm}$ ). The right eye was normal. The left eye was red, the ocular tension was raised, and there was corneal oedema. An aqueous flare and a small hyphaema were found. The lens was pushed forwards and subluxated below. Ectropion uveae and iris atrophy were present. The vitreous was filled with blood and no fundus view could be obtained. The eye was blind and painful and was therefore enucleated. Histological examination of the eye (Dr. G. Morgan) showed a total retinal detachment and changes similar to those seen in Coats's disease.

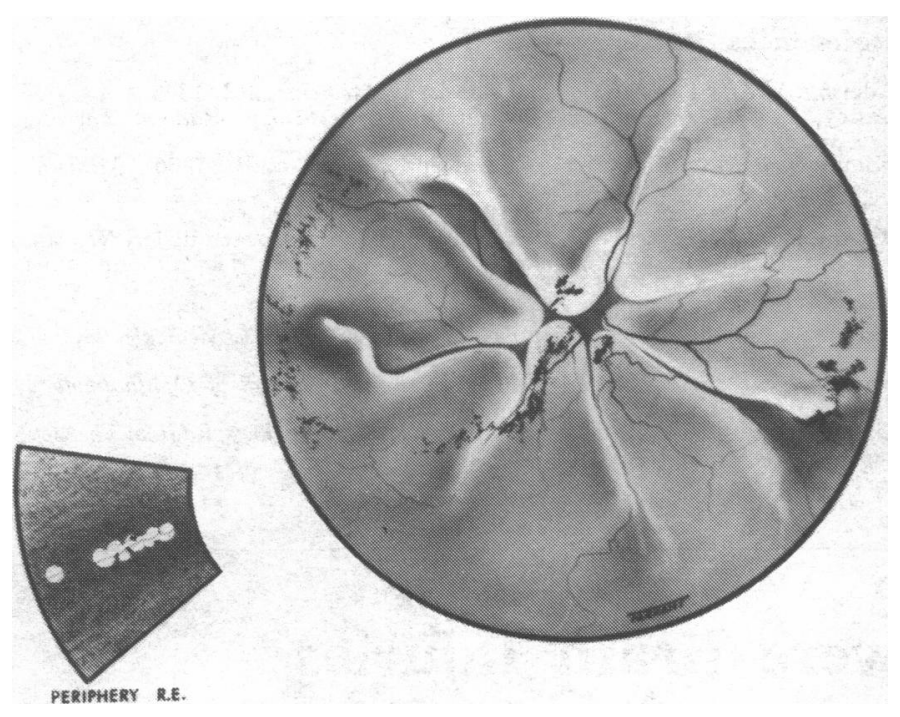

FIG. 2-Case 1. Left eye showing the total retinal detachment. Note the small area of scarring in the periphery of the right retina.

\section{Case 3}

This boy was admitted to hospital at the age of 4 months with bilateral subdural haematomata. No definite history could be obtained. The child was looked after by a baby-minder during the day while the parents were at work. He had been irritable for two days and there is strong circumstancial evidence that he was deliberately kicked on the head by the baby-minder's husband in an attempt to quieten him.

On admission he was drowsy and had extensive bilateral retinal haemorrhages. Repeated subdural taps were performed and he made a complete recovery. Ophthalmic examination three months later showed normal healthy eyes and normal retinae with no scarring, but he had partial optic atrophy. His vision will be impaired.

\section{Case 4}

This boy was first seen at the age of 4 months because of blood in the stools. He had abdominal bruising and was underweight. Though intussusception was considered, the diagnosis of trauma was thought most likely. He recovered and gained weight in hospital. Two months later he was seen elsewhere with a fractured tibia, supposedly having fallen over a step at home. At the age of 9 months he was admitted in a drowsy state and found to have bilateral subdural haematomata. Ophthalmic examination showed bilateral subhyaloid haemorrhages. Subdural taps were performed and $150 \mathrm{ml}$ of blood was evacuated. The mother was clearly afraid of the rather aggressive father (a merchant seaman) and the episode of trauma clearly corresponded with the father's return from sea. When tackled by the paediatrician about his attitude to the child the father became abusive and threatened the paediatrician. The child was taken to another hospital where he rapidly recovered and gained weight. The retinal haemorrhages completely absorbed in the right eye, but the left eye showed macular scarring. He had a left convergent squint and the vision in the left eye was likely to be very poor.

\section{Cases 5-12}

The clinical details of these eight cases are summarized in the Table. Five had subdural haematomata. Three became totally blind. All had permanent impairment of vision in one or both eyes.

Summary of 8 Cases of Battered-baby Syndrome with Ocular Involvement

\begin{tabular}{|c|c|c|c|c|c|c|}
\hline \multirow{2}{*}{$\begin{array}{l}\text { Case } \\
\text { No. }\end{array}$} & \multirow{2}{*}{$\begin{array}{c}\text { Age } \\
\text { in } \\
\text { Months }\end{array}$} & \multirow{2}{*}{ History } & \multirow{2}{*}{ Present Admission } & \multicolumn{2}{|c|}{ Findings } & \multirow{2}{*}{ Final Ocular State } \\
\hline & & & & General & Ocular & \\
\hline 5 & 13 & $\begin{array}{l}\text { 6/12: "failure to thrive" } \\
\text { 9/12: blood in stools }\end{array}$ & $\begin{array}{l}\text { "Fell off chair": later } \\
\text { discovered that father } \\
\text { had thrown her across }\end{array}$ & $\begin{array}{l}\text { Multiple bruises, } 3 \text { frac- } \\
\text { tured ribs, fractured hum- } \\
\text { erus, fractured skull }\end{array}$ & Not seen at time of injury & $\begin{array}{l}\text { Let optic atrophy. Left convergent } \\
\text { squint } 25^{\circ}\end{array}$ \\
\hline 6 & 10 & $\begin{array}{l}\text { 4/12: bruising of arm } \\
\text { and leg } \\
6 / 12: \text { fractured tibia }\end{array}$ & "Fell off high chair" & $\begin{array}{l}\text { Drowsy and ill; subdural } \\
\text { haematoma }\end{array}$ & $\begin{array}{l}\text { Bilateral subhyaloid hae- } \\
\text { morrhages. Left vitreous } \\
\text { haemorrhage }\end{array}$ & $\begin{array}{l}\text { Bilateral optic atrophy, bilateral } \\
\text { macular scarring. Infant is blind }\end{array}$ \\
\hline 7 & 14 & $\begin{array}{l}\text { 3/12: failure to thrive } \\
6 / 12: \text { fractured ribs } \\
10 / 12: \text { fractured tibia }\end{array}$ & $\begin{array}{l}\text { "Hurt himself playing" } \\
\text { (parents spoke little } \\
\text { English) }\end{array}$ & $\begin{array}{l}\text { Underweight, undernouri- } \\
\text { shed child. Multiple bruis- } \\
\text { ing especially around head } \\
\text { and neck }\end{array}$ & Not seen at time of injury & $\begin{array}{l}\text { Right convergent } 25^{\circ} \text {. Total right } \\
\text { retinal detachment }\end{array}$ \\
\hline 8 & 12 & $\begin{array}{l}\text { 9/12: multiple bruising } \\
10 / 12: \text { bruising on chest } \\
11 / 12 \text { : blood in stools }\end{array}$ & "Not well for two days" & $\begin{array}{l}\text { Semi-conscious, stiff neck, } \\
\text { underweight, fracture } \\
\text { parietal bone, bloodstained } \\
\text { C.S.F., subdural haema- }\end{array}$ & $\begin{array}{l}\text { Bilateral subhyaloid hae- } \\
\text { morrhage, breaking into } \\
\text { vitreous on left side }\end{array}$ & $\begin{array}{l}\text { Left convergent squint } 15^{\circ} \text {. Left } \\
\text { macular scarring. Right eye normal }\end{array}$ \\
\hline 9 & 3 & $\begin{array}{l}\text { 3/12: noticed to be } \\
\text { drowsy. Strong sus- } \\
\text { picion that baby- } \\
\text { minder threw feeding } \\
\text { bottle at baby's head }\end{array}$ & & $\begin{array}{l}\text { toma } \\
\text { Fracture right parietal, sub- } \\
\text { dural haematoma }\end{array}$ & $\begin{array}{l}\text { Extensive retinal and vitreous } \\
\text { haemorrhages both eyes, } \\
\text { no view of discs }\end{array}$ & $\begin{array}{l}\text { Right eye: preretinal fibrous mem- } \\
\text { brane over disc and scarred } \\
\text { macula. Peripheral retinal scarring } \\
\text { with retinal lifting at } 1 \text { o'clock. } \\
\text { Left eye: retinal scarring around } \\
\text { disc, macular cyst. } \\
\text { Registered as partially sighted }\end{array}$ \\
\hline 10 & 18 & 12/12: multiple bruising & $\begin{array}{l}\text { No history obtainable. } \\
\text { Father alcoholic. } \\
\text { Mother had walked } \\
\text { out } 2 \text { days previously }\end{array}$ & $\begin{array}{l}\text { Fractured skull, fractured } \\
\text { tibia and humerus, sub- } \\
\text { dural haematoma }\end{array}$ & $\begin{array}{l}\text { Extensive bilateral retinal } \\
\text { haemorrhages }\end{array}$ & $\begin{array}{l}\text { Bilateral optic atrophy. Right } \\
\text { macular scarring. E.E.G. shows } \\
\text { occipital lobe damage. } \\
\text { Child is blind }\end{array}$ \\
\hline 11 & 11 & $\begin{array}{l}\text { 6/12: multiple bruising, } \\
\text { failure to thrive }\end{array}$ & $\begin{array}{l}\text { "Fell down flight of } \\
\text { stairs while playing." } \\
\text { Almost certainly hit } \\
\text { by mother with broom }\end{array}$ & $\begin{array}{l}\text { Fracture of parietal and } \\
\text { occipital bones, subdural } \\
\text { haematoma }\end{array}$ & Not seen at time of injury & $\begin{array}{l}\text { (Mentally retarded.) Left pale disc, } \\
\text { normal pupil reactions, normal } \\
\text { retinae, absent visual evoked } \\
\text { responses, cortical blindness. }\end{array}$ \\
\hline 12 & 60 & $\begin{array}{l}8 \text { months: shoulder } \\
\text { injury } \\
\text { 18/12: fractured skull } \\
22 / 12: \text { multiple bruising } \\
\text { around head and neck }\end{array}$ & $\begin{array}{l}\text { Seen when taken into } \\
\text { care because of break- } \\
\text { down of parents' } \\
\text { marriage }\end{array}$ & & & $\begin{array}{l}\text { Right total retinal detachment. } \\
\text { Peripheral retinal scarring in left } \\
\text { eye }\end{array}$ \\
\hline
\end{tabular}




\section{Cases 13-19}

I have seen seven further cases of battered children with subdural haematomata who have had bilateral subhyaloid haemorrhages. The haemorrhages in these children resolved completely, leaving no sequelae. The children have normal vision.

\section{Comment}

It is not well recognized that permanent visual damage occurs in the battered-baby syndrome. Several of the cases described presented to an ophthalmologist on quite a different occasion, and at a different hospital, to that where they were seen by a paediatrician; thus the paediatrician in charge of the case was not aware that the child suffered any visual disability. Only by chance did I piece together the full history in the first two cases.

The series shows that severe and permanent ocular disease affects a substantial number of battered infants. Though retinal haemorrhages are common in the battered-baby syndrome they are minimal in most cases and undergo complete resolution. It is surprising that external damage to the eyes was not seen in this series, though it has been recorded in battered infants (Cameron et al., 1966). The two cases in which the retina was detached are of special interest in that considerable force is required to cause direct damage to the retina of a child; in one case the social worker suspected that the child had been picked up by the feet and its head repeatedly hit against the door. In nine cases there was a fracture of the skull or subdural haematoma. The associated retinal haemorrhage in four of these cases broke through into the vitreous and subsequently organized, with resultant permanent scarring at the maculae. In three cases cerebral damage led to optic atrophy. Two are in homes for the blind.

The eye that had to be removed showed histological changes similar to those in Coats's disease, and trauma may be the cause of some cases of this puzzling condition (Mushin and Morgan, 1971).

It is therefore evident that the diagnosis of battered-child syndrome must be considered in all cases of severe retinal disease and optic atrophy in childhood; and all infants suspected of being "battered babies" should be referred to an ophthalmologist for complete ocular examination, both at the time of injury and at follow-up.

I would like to thank the staff of Moorfields Eye Hospital and Hammersmith Hospital who have referred cases to me, and in particular Dr. Pamela Davies, Professor Barrie R. Jones, and Professor J. P. M. Tizard for their help in the preparation of this report.

\section{References}

Adelson, L. (1961). New England fournal of Medicine, 264, 1345. Adelson, L. (1961). American Journal of Roentgenology, Radium Therapy,

Cameron, J. M., Johnson, H. R. M., and Camps, F. E. (1966). Medicine, Science and the Law, 6, 2

Gilkes, M. J., and Mann, T. P. (1967). Lancet, 2, 468.

Kempe, L. H., Silverman, F. N., Steele, B. F., Droegemueller, W., and Silver, H. K. (1962). Journal of the American Médical Association, 181,14 .

Kiffney, G. T., jun. (1964). Archives of Ophthalmology, 72, 231.

Maroteaux, P., Fessard, C., and Aron, J. J. (1967). Presse Medicale, 75, 711. Maroteaux, P., and Lamy, M. (1967). Lancet, 2, 829.

Mushin, A. S., and Morgan, G. (1971). British fournal of Ophthalmology, $55,343$.

Silverman, F. N. (1953). American fournal of Roentgenology, Radium Therapy, and Nuclear Medicine, 69, 413.

\title{
Prognosis for Patients with Severe Brain Injuries
}

\author{
MATTI VAPALAHTI, HENRY TROUPP
}

British Medical fournal, 1971, 3, 404-407

\section{Summary}

Intraventricular pressure recording has been a standard procedure in the neurosurgical clinic, University Central Hospital, Helsinki, Finland, since 1964. Up to 31 December 1970, 250 recordings had been performed, 90 of these on brain-injured patients. Intraventricular pressure correlates well with survival or death of the patient but will not predict the quality of survival. However, other criteria seem to correlate well with the quality of survival.

The results of a prospective study of 50 patients between 1 January 1967 and 31 December 1969 are reported. Clues to vegetative survival are very low arterial $\mathbf{P C O}_{2}$ after a free airway has been established, a high respiratory minute volume, temperature above $39^{\circ} \mathrm{C}$, CheyneStokes breathing, and extension rigidity in adults.

Neurosurgical Clinic, Helsinki University Central Hospital, Helsinki, Finland

MATTI VAPALAHTI, L.K.T.

HENRY TROUPP, L.K.T.
When a reliable prognosis can be established that the patient is going to survive only as a vegetative wreck it is highly doubtful if the whole might of modern intensive therapy should be applied.

\section{Introduction}

In spite of all technical advances over the past 20 years many patients still die from brain injury, while some-perhaps the most distressing category among those who survive-will remain purely vegetative beings. We are trying to establish criteria whereby an injury so severe as to lead to merely vegetative survival can be detected at an early stage. Modern methods of care allow such a patient to continue his "posthumous" (Keats, 1948) existence indefinitely, and it is increasingly evident that the difference in outcome (early death, long vegetative survival, or recovery) lies more with the injury than with failure of treatment immediately after the injury. It is out contention that heroic measures are unnecessary if prognosis can be made so certain that injuries leading to early death or vegetative survival can be accurately distinguished from injuries giving a hope of recovery as a social human being.

The death of a patient with brain injury can be predicted days in advance by means of recording the intraventricular pressure (Lundberg et al., 1965; Troupp, 1965, 1967; Johnston et al., 1970; Richardson et al., 1970). A large series has been 